\title{
Cultura popular: as construções de um conceito na produção historiográfica
}

\section{Popular culture: the construction of a concept of historiographic production}

Petrônio DOMINGUES*

Resumo: A proposta central deste artigo é fazer uma discussão em torno da construção do conceito de cultura popular. Também serão efetuados, num segundo momento, breves apontamentos acerca do conceito de “cultura popular negra”. A ideia central aqui é mostrar que, na produção do conhecimento histórico, consolida-se a tendência de questionar as delimitações essencialistas que separam cultura popular e erudita (ou de elite) em compartimentos estanques.

Palavras-chave: Cultura. Popular. Negro. Afrodiáspora.

\begin{abstract}
The purpose of this article is to raise a discussion on the construction of the concept of popular culture. Also brief notes will be made concerning the concept of "black popular culture”. The central idea here is to show that, in the production of historical knowledge, it is a consolidated trend to question the essentialists' delimitations that separate popular and erudite or elite culture into tight compartments.
\end{abstract}

Keywords: Culture. Popular. Black population. African Diaspora.

Na cultura popular negra, estritamente falando, em termos etnográficos, não existem formas puras.

(HALL, 2003, p.343).

A finalidade precípua deste artigo é dissecar a construção dos conceitos de cultura popular e erudita (ou de elite) na produção do conhecimento histórico e, num segundo e último momento,

\footnotetext{
* Professor Adjunto da Universidade Federal de Sergipe, Centro de Educação de Ciências Humanas - Cidade Universitária Prof. José Aloísio de Campos. Jardim Rosa Else. Cep: 49100-000 - São Cristóvão, SE - Brasil. E-mail: pjdomingues@yahoo.com.br.
} 
tecer breves apontamentos acerca do conceito de "cultura popular negra”, cunhado por Stuart Hall. Antes, porém, serão esquadrinhados alguns autores clássicos - Mikhail Bakhtin, Michel de Certeau, Carlo Ginzburg, Robert Darnton, Roger Chartier, Peter Burke e Edward Palmer Thompson. Seus textos, em certos pontos, convergem na compreensão do que seja popular, em outros, dialogam entre si, mas antes eles divergem. Os autores realizaram suas investigações de forma interdisciplinar, estabelecendo confluências e transposições entre várias áreas das ciências humanas: história, sociologia, antropologia e crítica literária, principalmente. A ideia central aqui é mostrar que, na produção do conhecimento histórico, consolida-se a tendência de questionar as abordagens essencialistas que separam cultura popular e erudita em compartimentos estanques.

A separação desses dois polos foi uma invenção dos intelectuais europeus, na segunda metade do século XVIII. Por meio do conceito de folclore ("saber do povo”), eles demarcaram a fronteira das manifestações culturais das camadas sociais abastadas em relação àquelas mais amplamente difundidas. Nos séculos XIX, o povo - não os setores marginalizados das cidades, e sim os habitantes das zonas rurais - foi idealizado, com sua produção cultural tendo sido retratada como "pura”, "natural” e “resíduo” do passado. Essa idealização serviu de base para a elaboração do mito fundador de várias nações, bem como desencadeou o início de muitas pesquisas folclóricas que se empenharam em descobrir uma cultura "primitiva”. Segundo essas pesquisas, as manifestações folclóricas, herdadas do mundo rural, estavam condenadas à morte, devido ao seu crescente contato com influências “deletérias” dos centros urbanos (BURKE, 1989; CERTEU; JULIA; REVEL, 1989, p.63). Entretanto, ao longo do século XX, após uma série de estudos que se debruçou sobre as manifestações populares “sobreviventes”, essa concepção foi se tornando cada vez mais insustentável. Batizou-se, então, a categoria “cultura popular” no lugar da restritiva "folclore".

Com efeito, uma questão controversa ainda permaneceu. O que seria “popular”? O termo popular é derivado de povo. E o que seria um “povo”? Não há consenso na resposta; a acepção mais comum é considerar povo como o conjunto dos cidadãos de um país, excetuando-se os dirigentes e os membros da elite socioeconômica. Se não há consenso em torno do termo “povo”, o que dizer do conceito de “cultura”? Peter Burke julga que esse conceito parece ser ainda mais controverso. Antes, era usado para se referir à “alta” cultura, mas, hodierno, o uso do termo foi ampliado, incorporando a "baixa” cultura, ou cultura popular. Em outras palavras, o termo cultura geralmente se relacionava à literatura (acadêmica), música (clássica) e ciência. Depois, ele passou a ser empregado para caracterizar os seus correspondentes populares - literatura de cordel, canções folclóricas e medicina popular. Atualmente, o conceito de cultura tem um sentido bastante dilatado, abrangendo praticamente tudo que pode ser apreendido em uma sociedade - desde uma variedade 
de artefatos (imagens, ferramentas, casas e assim por diante) até práticas cotidianas (comer, beber, andar, falar, ler, silenciar) (BURKE, 2005, p.42).

Em livro recentemente publicado no Brasil, Jacques Revel também salienta o processo de redefinição da noção de cultura ou, antes, daquilo que os historiadores evocam sob esta rubrica. Durante muito tempo existiu uma visão dominante - e limitadora - do campo de atuação da história da cultura. Ela se interessava pelos autores e pelas obras, ou seja, por um repertório mais ou menos canônico de obras que era preciso levar a sério, conhecer, apreciar, conservar e transmitir de geração em geração, uma cultura legítima e, de certa maneira, obrigatória. Vários especialistas assumiram a tarefa de estudá-la: a história das ideias, a da literatura, a das artes, a das ciências etc. Essa definição limitadora foi substituída por outra que, no decorrer da última geração, ocupou o centro das atenções. Trata-se de uma definição muito mais ampla, ambiciosa, a propósito da qual se fala amiúde, sem nem sempre especificar o que se entende por cultura no sentido antropológico do termo. Na opinião de Revel, essa incerteza é cômoda para os historiadores “e pode, aliás, colocar rapidamente problema, já que os antropólogos propuseram um número bastante grande de definições da cultura, que frequentemente são conflitantes e até mesmo incompatíveis entre si” (REVEL, 2009, p.100).

Seja como for, a reflexão acerca da cultura popular entrou na moda no último quartel do século XX (VOVELLE, 1991, p.153). As razões desse interesse pelo popular relacionavam-se às mudanças epistemológicas de Clio. A partir do momento em que a oficina da história passou a se interessar pelos anônimos em detrimento de personagens "ilustres”, reis, heróis e tramas palacianas, o pesquisador viu-se no dever de dar voz à arraia-miúda. A mudança de paradigmas (e utensilagens) foi acelerada na medida em que as sociedades ocidentais conheceram, mais cedo ou mais tarde, uma espetacular experiência de massificação da cultura: do livro de bolso à televisão, uma nova circulação de práticas culturais, de transferência de valores, produtos e saberes, convidava, por sua vez, a questionamentos sobre as formas das "partilhas culturais, sobre as resistências à difusão e sobre as hipóteses de uma cultura de massas” (REVEL, 1989, p.45).

Assistiu-se, então, a um amplo (e polêmico) debate, com os autores muitas vezes tomando posições díspares. Na visão tradicional, cultura popular consiste em todos os valores materiais e simbólicos (música, dança, festas, literatura, arte, moda, culinária, religião, lendas, superstições etc) produzidos pelos extratos inferiores, pelas camadas iletradas e mais baixas da sociedade, ao passo que cultura erudita (ou de elite) é aquela produzida pelos extratos superiores ou pelas camadas letradas, cultas e dotadas de saber ilustrado. No entanto, esta divisão rigorosa não se confirma 


\section{Petrônio Domingues}

empiricamente, pelo menos é o que as pesquisas no terreno da história cultural, antropologia, sociologia e teoria literária vêm demonstrando ultimamente.

\section{Cultura popular: um campo de disputas}

O livro A cultura popular na Idade Média e no Renascimento: o contexto de François Rabelais, do crítico literário russo Mikhail Bakhtin, é um marco nos estudos da cultura popular. Essa temática é perscrutada com a pretensão de nela encontrar as matrizes explicativas da obra do escritor francês François Rabelais. Para contextualizar o leitor na problemática do autor renascentista, Bakhtin elabora uma teorização do cômico e da cultura popular da Idade Média e do Renascimento. Sublinha que o riso, o burlesco e o aspecto jocoso das manifestações culturais populares tinham a capacidade de produzir uma "dualidade do mundo", configurando-se uma oposição à cultura oficial (da Igreja e do Estado). Mais ainda. A cultura cômica popular expressou a visão de mundo peculiar das camadas inferiores da sociedade. Mas, apesar disso, esta manteve um permanente, orgânico e dinâmico contato com a cultura oficial, influenciando e sendo influenciada por ela (BAKHTIN, 1987).

A relação entre a cultura erudita (ou da elite intelectual) e a cultura popular passa tanto pelas formas quanto pelos conteúdos dos sistemas de representações. Por isso o cruzamento entre ambos os domínios não pode ser entendido como uma relação de exterioridade envolvendo dois conjuntos estabelecidos aprioristicamente e sobrepostos (um letrado, o outro iletrado). Pelo contrário, esse cruzamento - ou zonas de fronteiras - entre o chamado "erudito” e o "popular” produz encontros e reencontros, espécie de fusões culturais. Segundo Bakhtin, em determinados momentos o Renascimento se traduzia na cultura popular codificada nas obras da cultura letrada ou erudita. Aliás, foi na cultura popular que todo aquele sistema cultural encontrou a sua máxima coerência e revelou de forma mais cabal seu princípio. A obra de Rabelais, nesse sentido, é paradigmática, justamente porque penetra no âmago da “cultura cômica popular”, ou seja, na verdadeira “enciclopédia” da cultura popular ( BAKHTIN, 1987 , p.50).

O que se qualifica de “erudito” e o “popular” está em permanente processo de ajustes, desajustes, reajustes, em suma, em movimento. Assim, tornar indissociável a divisão entre eles é anular os postulados metodológicos que procuram conferir um tratamento contrastado de um e de outro domínio.

Em artigo polêmico (A beleza do morto: o conceito de cultura popular), Michel de Certeau, Dominique Julia e Jacques Revel declaram que cultura popular pressupõe uma operação difícil de reconhecer. Centrados sobretudo na experiência dos estudos consagrados aos colportage (folhetos 
conhecidos aqui como literatura de cordel), os autores observam como as elites francesas do século XIX procuraram censurar e patrulhar, por meio da concessão de licenças, o conteúdo desses livros. Vistos como contrários à ordem, à moral e à religião, os colportages foram perseguidos, retirados de circulação e condenados ao perecimento. Não obstante, tal medida repressiva deu origem à curiosidade científica. As elites intelectuais se interessaram em "salvar” os colportages. Para tanto, embalsamaram-nos como coisa inofensiva, exótica e em extinção.

$\mathrm{Na}$ contramão das explicações correntes, os historiadores franceses argumentam que a cultura popular resultou de uma fabricação deliberada das elites: concordava-se em exaltar a inocência e a importância da cultura popular quanto mais se mobilizava para acelerar sua morte. Os autores falam da "beleza do morto” para se referirem à atitude das elites de só atribuírem valor às manifestações da cultura popular quando estas não representam mais perigo, ou seja, estão mortas. A cultura popular, por essa perspectiva, significa uma “sombra”, um “fantasma” e um "enigma da Esfinge”. Não é de estranhar “que este objeto assuma a imagem de uma origem perdida: a ficção de uma realidade a encontrar mantém a marca da ação política que a organizou” (CERTEU; JULIA; REVEL, 1989, p.63). Assim, “onde estamos, senão no seio da cultura erudita? Ou, se se quiser: a cultura popular existirá fora do ato que a suprime?”1 (CERTEAU; JULIA; REVEL, 1989, p.74).

Se os historiadores franceses desqualificam, conceito de cultura popular quando não sugerem a nulidade do uso do, Carlo Ginzburg o revaloriza. No prefácio à edição italiana de seu livro O queijo e os vermes: o cotidiano e as idéias de um moleiro perseguido pela inquisição, o historiador italiano empreende um balanço crítico de algumas obras que enfocaram o assunto e replica Michel de Certeau, Dominique Julia e Jacques Revel: não se deve “jogar a criança fora junto com a água da bacia - ou, deixando de lado as metáforas, a cultura popular junto com a documentação que dela nos dá uma imagem mais ou menos deformada” (GINZBURG, 2002, p.1617). Não é preciso exagerar quando se fala em “filtros” e “intermediários”. O fato de uma fonte produzida pelas classes dominantes não ser “objetiva” (mas nem mesmo um inventário é “objetivo”) não significa que seja “inutilizável” (GINZBURG, 2002, p.20).

Para Ginzburg, o uso do termo cultura para designar o conjunto de práticas, atitudes e códigos de comportamentos próprios das classes subalternas é algo tardio e foi emprestado da antropologia cultural. Graças ao conceito de “cultura primitiva” reconheceu-se que aquelas pessoas, outrora definidas de forma paternalista como "camadas inferiores dos povos civilizados”, eram dotadas de cultura. Superou-se, assim, a posição daqueles que identificavam nas ideias, crenças, visões de mundo das classes subalternas, apenas “um acúmulo desorgânico de fragmentos de ideias, 
crenças, visões de mundo elaborados pelas classes dominantes provavelmente vários séculos antes” (GINZBURG, 2002, p.16-17).

Ginzburg constata que apenas "recentemente”"2 os historiadores encamparam a temática do popular. Isso teria ocorrido por dois motivos: um ideológico e o outro metodológico. Do ponto de vista ideológico, foi superada a visão de considerar as “crenças e idéias originais” apenas aquelas provenientes das classes superiores; a concepção de que tais “crenças e idéias originais” das classes superiores eram tão deformadas no processo de difusão e transmissão para as classes subalternas que estas não mereciam ser levadas a sério. Já do ponto de vista metodológico, refere-se ao fato de as culturas das classes subalternas serem predominantemente orais, fato, aliás, que é acentuado à medida que se recua no tempo. Diante da impossibilidade de entrevistar camponeses do século XV, por exemplo, o historiador tem que se valer de fontes indiretas: que foram escritas e, em geral, de autoria de pessoas que não pertenciam a tais classes, e que muitas vezes assumiam uma postura de oposição a elas. Nesse caso, o historiador deverá ser cioso, pois, como foi assinalado, terá acesso a aspectos da cultura popular mediado por filtros e intermediários.

No prefácio à edição inglesa de $O$ queijo e os vermes, Ginzburg se reporta a Mikhail Bakhtin. E, valendo-se dele, menciona o termo “circularidade”, para delinear a comunicabilidade que havia entre a cultura das classes dominantes e a das classes subalternas na Europa préindustrial. Essa comunicação se dava de forma dialógica, com "influências recíprocas, que se moviam de baixo para cima, bem como de cima para baixo”(GINZBURG, 2002, p. 12).

Já Robert Darnton, no seu livro O grande massacre de gatos, e outros episódios da história cultural francesa, investiga o universo mental dos não “iluminados”. Seu método, que denomina como uma história de tendência etnográfica, procura examinar “as maneiras de pensar na França do século XVIII. Tenta mostrar não apenas o que as pessoas pensavam, mas como pensavam - como interpretavam o mundo, conferiam-lhe significado e lhe infundiam emoção” (DARNTON, 2001, p.XIII). Darnton diferencia a história cultural, à qual se alinha, da história das ideias. Esta se preocupa com o pensamento que foi sistematizado e formalizado, ao passo que aquela aborda como as pessoas dos segmentos subalternos entendiam o mundo. Além disso, esse método intenciona explicitar as estratégias implementadas por esses segmentos em seu cotidiano. Ao contrário de um pensamento mais abstrato, de tipo filosófico, as "pessoas comuns pensam com coisas” ou com outros materiais que sua cultura disponibilize, como histórias, símbolos ou cerimônias (DARNTON, 2001, p.XIV) ${ }^{3}$. A pesquisa de Darnton é toda permeada pela noção de leitura. Para ter acesso aos modos de pensar do "homem comum” do século XVIII, o historiador norte-americano “bebe” nas ideias do antropólogo Clifford Geertz, sobretudo, quando sinaliza a possibilidade de ler as práticas sociais como se fossem textos. 
Cultura popular: as construções de um conceito na

produção historiográfica

Roger Chartier discorda dessa metodologia. Na verdade, ele até reconhece que muitas vezes o historiador tem acesso às práticas sociais do passado por meio de textos. Porém, o fundamental na pesquisa seria conseguir entender as relações entre o texto e as práticas às quais ele se refere. $\mathrm{O}$ texto deve ser concebido como mediação, não devendo, portanto, ser pensado como possuindo uma identidade imediata com as práticas. No artigo Cultura popular: revisitando um conceito historiográfico, Chartier apresenta seu entendimento da questão da cultura popular. De forma um tanto quanto esquemática, ele reduz as diversas definições da cultura popular a dois modelos de abordagem e interpretação:

O primeiro, no intuito de abolir toda forma de etnocentrismo cultural, concebe a cultura popular como um sistema simbólico coerente e autônomo, que funciona segundo uma lógica absolutamente alheia e irredutível à da cultura letrada. O segundo, preocupado em lembrar a existência das relações de dominação que organizam o mundo social, percebe a cultura popular em suas dependências e carências em relação à cultura dos dominantes. Temos, então, de um lado, uma cultura popular que constitui um mundo à parte, encerrado em si mesmo, independente, e, de outro, uma cultura popular inteiramente definida pela sua distância da legitimidade cultural da qual ela é privada. (CHARTIER, 1995, p.179).

Chartier verifica que esses dois modos de explicação não são necessariamente conflitantes, ocorrendo, também, o uso de ambos por um mesmo autor, ou numa mesma obra. Entretanto, o importante para ele é identificar como se opera esse relacionamento entre as formas impostas e aculturantes, de um lado, e as táticas agenciadas pelos segmentos subalternos, por outro. Haveria um espaço entre as “injunções constrangedoras” e a recepção “rebelde” e “matreira”. É nesse espaço que se dá o uso ou, melhor dizendo, os modos de usar objetos, discursos, comportamentos, hábitos, crenças, modelos culturais etc. por parte do "popular”. De acordo com Chartier, são nos modos de usar, como práticas sociais, que se deve encontrar o “popular” (CHARTIER, 1995 p.185). A questão dos usos, por sua vez, está diretamente relacionada ao conceito de apropriação. É por meio da apropriação que os setores não hegemônicos operam a "produção de sentidos”, ou seja, que a recepção se torna “matreira” e “rebelde”. Com um procedimento metodológico centrado na apropriação, o historiador francês tenta superar as abordagens que adjetivam a cultura popular como universo simbólico ora autônomo ora dependente.

Colocar em xeque a dicotomia erudito/popular conduz a outra problemática, que tem implicações metodológicas na produção historiográfica: a oposição entre criação e consumo, entre produção e recepção. No livro A história cultural: entre práticas e representações, Roger Chartier se debruça sobre essa problemática. Seu argumento é de que a separação radical entre produção 
(cultura erudita) e consumo (cultura popular) leva a pensar que as ideias ou as formas têm vida autossuficiente, totalmente independente de sua apropriação para um grupo de sujeitos. Agir como se os textos (ou imagens) tivessem significados em si mesmos, fora das leituras que lhes conferem sentidos, é elevar tais textos e imagens ao estatuto de categorias absolutas e universais, em última instância, a-históricas. Restituir a historicidade do objeto exige que o “consumo” cultural seja concebido, também, como uma produção, que, apesar de não fabricar nenhum outro objeto, constitui representações que nunca são idênticas às que o produtor (intelectual), o autor (erudito) ou artista, impingiu na sua obra. Por esse motivo, “anular o corte entre produzir e consumir”, infere Chartier, “é antes de mais nada afirmar que a obra só adquire sentido através da diversidade de interpretações que constroem as suas significações. A do autor é uma entre outras, que não encerra em si a 'verdade’ suposta como única e permanente da obra” (CHARTIER, 1988, p.59).

Se o consumo cultural pode ser qualificado, no limite, de uma “outra produção”, a leitura de um texto pode transcender à passividade que tradicionalmente lhe é atribuída. Ler, olhar, escutar são, efetivamente, exercícios intelectuais que, em vez de moldar linearmente o consumidor (popular) à mensagem ideológica (erudita), permitem uma aproximação, reaproximação, distanciamento ou, simplesmente, resistência. Essa constatação leva o historiador a repensar a relação entre um público designado como popular e os produtos intelectuais (livros e imagens, discursos, canções e, mais recentemente, emissões radiofônicas, televisivas e eletrônicas) propostos para o seu consumo (CHARTIER, 1988, p.59-60). A decodificação pelas classes populares desses materiais é uma das chaves que permitem elucidar como a cultura popular pode em qualquer época construir um lugar, reinterpretar, ou instaurar um sentido próprio nos modelos que lhes são impostos pela classe dominante, portadora da cultura “erudita”.

Com o livro Cultura popular na Idade Moderna, Peter Burke lança luz sobre o tema da cultura popular no conjunto da Europa (“da Noruega à Sicília, da Irlanda aos Urais”). Aponta que a noção de cultura popular é problemática. Existiam muitas “culturas populares ou muitas variedades de cultura popular - é difícil optar entre as duas formulações porque uma cultura é um sistema de limites indistintos, de modo que é impossível dizer onde termina uma e começa outra” (BURKE, 1989, p.56).

O historiador inglês alega que outra grande dificuldade de definir a cultura popular decorre do fato de ela abrigar uma série de pontos de intersecção com a cultura erudita. A título de exemplo, ele observa que a cultura popular, no transcorrer da Idade Moderna, foi identificada tanto nos pequenos livros escritos por pessoas simples do povo - conhecidos como "literatura de cordel” quanto num conjunto de crenças tidas como formadoras de uma religião popular. Nestes dois casos, o popular é conceituado em oposição, primeiro, à literatura qualificada como erudita e letrada, e, 
segundo, ao catolicismo institucional da Igreja no período. Todavia, essa divisão no corpus documental é mais aparente do que se imagina. Afinal, a literatura “popular” alimentou as leituras (ou escritas) da sociedade camponesa ou de um público intermediário, situado entre o povo analfabeto e uma ínfima minoria de letrados (BURKE, 1989, p.95-99). Em última instância, não seria possível sustentar que este tipo de literatura era compartilhado por toda a sociedade e que cada grupo decifrava seu código cultural à sua maneira? Da mesma maneira, não seria possível formular as seguintes indagações: A religião “popular” era exclusivamente praticada pelos camponeses, pelo conjunto dos dominados? Mais: Este tipo de religiosidade contrastava totalmente com as práticas religiosas cotidianas da elite?

O fato é que a fronteira entre as várias culturas do povo e as culturas das elites é vaga, movediça, pantanosa, por isso Burke afirma que a atenção do historiador deve concentrar-se na interação e não na divisão entre elas. Ele cunha o termo "bicultural” para descrever a situação de membros da elite que se enfronharam nas práticas culturais populares e que, ao mesmo tempo, participavam de uma cultura “alta”, ensinada “em escolas secundárias, universidades, cortes etc., às quais as pessoas comuns não tiveram acesso” (BURKE, 1989, p.17). Vale reiterar essa ideia do autor: não é possível aquilatar rigorosamente o que seria de “natureza” popular, num universo social complexo e no qual se envolve a troca de práticas e objetos culturais múltiplos. No curso da pesquisa, o historiador “descobrirá” que a cultura do povo se apresenta, sempre, como um conjunto misto que reúne, numa colcha de retalho, formas e elementos culturais de origens diversas.

Já no seu livro de coletânea Variedades de história cultural, o historiador inglês reserva um capítulo para investigar a cultura popular e erudita na Itália do Renascimento. Sua proposição é de que os historiadores da cultura italiana desse período têm que lidar com um processo de mão dupla. De um lado, houve a transmissão das formas e ideias das elites para o povo, sua difusão social, bem como geográfica. Usando uma metáfora espacial, ele designa isso de movimento "de cima para baixo”. Do outro lado, houve um movimento de "baixo para cima”, em que "pintores e escritores italianos recorreram à herança popular (BURKE, 2000, p.180). Novamente, Burke sugere que seria mais proveitoso estudar as interações entre a cultura popular e a de elite, em vez de tentar definir o que as separa. Não obstante, se o pesquisador assim o proceder, precisa certificar-se do polimorfismo desse processo. Há uma variedade de relações possíveis entre alta e baixa culturas: os usos da cultura popular por escritores renascentistas, os usos do Renascimento pelas pessoas comuns e, por fim, “a importância da 'viagem circular' de imagens e temas, uma viagem circular em que o que retorna jamais é o mesmo que partiu” (BURKE, 2000, p.193). 
Em obra mais recente - O que é história cultural? - o historiador inglês revisita o território da cultura popular. Entende que a dificuldade de se compreender essa questão começa pela própria definição de “povo”. Quem é o “povo”? Todos, ou apenas quem não é da elite? Neste último caso, não se estaria correndo o risco de supor a homogeneidade dos excluídos. O melhor seria pensar as culturas populares no plural, urbana e rural, masculina e feminina, velha e jovem, e assim por diante. No entanto, lembra Burke, essa solução gera um novo problema. Existe, na mesma sociedade, por exemplo, uma cultura feminina autônoma, distinta da cultura dos homens?

Responder "não" é negar diferenças palpáveis, mas responder "sim” talvez seja exagerá-las. Pode ser mais esclarecedor pensar em termos de culturas ou 'subculturas' femininas mais ou menos autônomas ou demarcadas. Serão mais autônomas sempre que as mulheres forem mais segregadas dos homens; por exemplo, nos conventos, no mundo mediterrâneo tradicional ou na cultura islâmica. (BURKE, 2005, p.41).

Outro problema para os historiadores que trabalham com a cultura popular é decidir se devem ou não incluir as elites, pelo menos em determinados períodos. Se decidir pela exclusão, é algo problemático, pois as pessoas de grande prestígio, poder econômico e político não seriam necessariamente diferentes, no que tange à prática cultural, das pessoas comuns. Burke observa que os leitores dos livrinhos baratos tradicionalmente descritos como exemplos de cultura popular na França do século XVII incluíam mulheres da nobreza e até mesmo uma duquesa (BURKE, 2005, p.41). Devido a tantos imbróglios, Roger Chartier postula que não é possível designar objetos ou práticas culturais como “populares”. E não é só ele que pensa assim; outros especialistas, como Peter Burke, vêm sugerindo que trocas dialógicas tão aprofundadas entre cultura erudita e popular são razões suficientes para abandonar de vez o uso dos dois adjetivos (BURKE, 2005, p.42) ${ }^{4}$. Eis uma posição controversa que, embora sedutora, não fica isenta de críticas.

Em seu livro de coletânea Costumes em comum: estudos sobre a cultura popular tradicional, o marxista Edward Palmer Thompson procurou discorrer sobre o tema do "costume” e como este se manifestou na cultura dos trabalhadores (camponeses e artesãos) ingleses, sobretudo no século XVIII. Defende que, nesse período, houve uma dissociação entre as culturas "plebéia e patrícia”. E esta divisão se deu em termos de classe - entre os de alta e os de baixa posição social, entre pessoas ricas com bens independentes e o grupo dos desagregados e desordeiros, entre os bem-nascidos e os sem berço. Uma cultura popular costumeira, alimentada por experiências bem distintas daquelas da cultura de elite, transmitida por tradições orais, reproduzida pelo exemplo, expressa pelo simbolismo e pelos rituais, situava-se a "uma distância muito grande da cultura dos governantes da Inglaterra” pós-Restauração (THOMPSON, 1998, p.69). 
De acordo com o historiador inglês, não se deve subestimar o processo criativo de formação de cultura a partir de baixo. Não só os elementos mais óbvios - as “canções folclóricas, os clubes dos ofícios e as bonecas de sabugo" - eram ali criados e recriados, mas também as expectativas, satisfações e interpretações da vida. A seu modo peculiar e talvez estranho, a "venda da esposa” desempenhava o papel de um divórcio ritual mais acessível que qualquer outro expediente que a cultura de elite pudesse oferecer. Os rituais da rough music, por mais cruéis que às vezes pareciam, não eram mais vingativos nem mais pitorescos que os rituais de uma “comissão especial de julgamento”. Se é verdade que a cultura plebeia, com suas próprias simbologias, tradições e superstições, interagia e negociava com a cultura de elite, ambas não se confundiam.

Refutando de forma explícita Peter Burke - e tacitamente Roger Chartier -, Thompson preconiza a existência de uma cultura popular, tradicional e relativamente independente (nem sempre ligada à Igreja ou às autoridades). Mas longe de exibir a permanência sugerida pela palavra “tradicional”, a cultura popular era um campo para a mudança e disputa. Longe de práticas uniformes, homogêneas e consensuais, era uma arena na qual interesses opostos apresentavam posições heterogêneas e conflitantes. Eis o motivo pelo qual se faz necessário ter cuidado quanto ao uso (abusivo) do conceito de cultura popular. Além de um "sistema de atitudes, valores e significados compartilhados, e as formas simbólicas (desempenho e artefatos) em que se acham incorporados” - como define Burke -, cultura é “um conjunto de diferentes recursos, em que há sempre uma permuta entre o escrito e o oral, o dominante e o subordinado, a aldeia e a metrópole”. É um domínio de elementos conflitivos, que somente sob uma pressão imperiosa - por exemplo, o nacionalismo, a consciência de classe ou a ortodoxia religiosa predominante - assume a forma de um “sistema”. E na verdade, adverte Thompson, “o próprio termo cultura, com sua invocação confortável de um consenso, pode distrair nossa atenção das contradições sociais e culturais, das fraturas e oposições existentes dentro do conjunto” (THOMPSON, 1998, p.17).

Por essa premissa, cultura deve ser pensada como um campo de disputas, confrontos, dissensões e contradições - inclusive no terreno popular. Conceito vazio se utilizado como generalização universal, ele só vai ter algum significado quando inserido num contexto histórico específico ou, nos termos postos pelo historiador inglês, quando "situado no lugar material que lhe corresponde”. A “cultura plebéia” não se autodefinia, nem era isenta de influências externas. Assumia sua forma numa condição defensiva, porém em rota de colisão aos limites e controles impostos pelos governantes "patrícios”: 
Espero que a cultura plebéia [seja] um conceito mais concreto e utilizável, não mais situado no ambiente de "significados, atitudes, valores", mas localizado dentro de um equilíbrio particular de relações sociais, um ambiente de trabalho de exploração e resistência à exploração, de relações de poder mascaradas pelos rituais do paternalismo e da deferência. (THOMPSON, 1998, p.17).

Tanto em sua coletânea Costumes em comum quanto em As peculiaridades dos ingleses $e$ outros artigos, Thompson se inspira no intelectual comunista italiano Antonio Gramsci e lança mão da categoria "hegemonia" ${ }^{5}$ para se referir à estrutura de dominação da gentry na vida inglesa do século XVIII. Seu argumento é de que a hegemonia cultural dos “governantes”, embora definisse os limites do que era possível e inibisse as expectativas alternativas por parte do “povo”, só podia ser sustentada com habilidade (uma mescla de repressão e constantes negociações e concessões). Mesmo assim, essa hegemonia jamais foi bem sucedida a ponto de impor uma única visão de mundo. Pelo contrário, ela coexistia com uma cultura “vigorosa e autônoma” do povo, derivada de suas próprias experiências e recursos (THOMPSON, 1998, p.79). O povo “faz e refaz sua própria cultura”, enfatiza Thompson (2001, p.211) Por meio de vários exemplos, o historiador inglês busca evidenciar o potencial dinâmico: ora de insubordinação, ora de acomodação das classes sociais subalternas frente aos poderes hegemônicos.

\section{Cultura popular negra}

Chegou a hora de examinar de que maneira Stuart Hall se posiciona nesse debate e desenvolve o conceito de “cultura popular negra”. Antes, porém, duas ou três notas biográficas desse autor. Nascido em Kingston, na Jamaica em 1932, e oriundo de uma família negra de classe média, Hall migrou para a Inglaterra no início da década de 1950, a fim de dar prosseguimento aos seus estudos. Em Oxford, se matriculou no curso de Letras e cerrou fileiras tanto nos grupos nacionalistas de países colonizados quanto nos círculos da esquerda marxista. No tocante ao marxismo, fez parte de um grupo fundamental para a formação da New Left inglesa, que incluía E. P. Thompson, Raymond Williams, Raphael Samuel e Charles Taylor. Em 1957 assumiu o cargo de professor em uma escola secundária em Brixton, no Sul de Londres, onde desenvolveu um projeto pedagógico fundado nas práticas culturais. Em 1961, começou a ministrar um curso sobre mídia e cinema no Chelsea College da Universidade de Londres. Três anos depois, escreveu, em conjunto com Paddy Whannel, seu primeiro livro, The popular arts, pautando mormente o jazz.

Em 1964, foi convidado por Richard Hoggart para acompanhá-lo na fundação do Centre for Contemporary Cultural Studies (CCCS), da Universidade de Birmingham. Considerado, por isso, um dos “pais” dos Estudos Culturais, Hall foi o primeiro diretor do CCCS, coordenando 
importantes projetos de pesquisas sobre classes sociais, questões de gênero, televisão, música pop, cinema, literatura e culturas juvenis (leia-se teds, mods, skinheads e rastas) ${ }^{6}$. Em 1979, transferiu-se para a Open University, onde deu continuidade às suas pesquisas na área dos estudos culturais e se consolidou como um dos intelectuais de referência na discussão de temas como pós-modernismo, o lugar da história no estudo da cultura contemporânea, desconstrução e empréstimos teóricos, meios de comunicação, pós-colonialismo, identidade e multiculturalismo. Nem sempre é fácil dissociar de seus textos as dimensões acadêmicas e políticas, já que ele é avesso a esse tipo de separação e se notabilizou pela capacidade de transformar os dilemas de seu tempo em novos objetos e questionamentos de pesquisa (MATTALART, 2004, p.58-59).

No Brasil, Hall publicou o livro de coletânea Da diáspora: identidades e mediações culturais, em 2003; três anos depois, foi a vez do A identidade cultural na pós-modernidade. Assim como E. P. Thompson, o intelectual jamaicano foi influenciado pela tradição marxista especialmente valeu-se das inovações teórico-conceituais engendradas por Richard Hoggart, Raymond Williams e Antonio Gramsci -, razão pela qual ele não perde de vista as “condições sociais e materiais de classes específicas” na análise do cultural. Sua preocupação central é compreender em que medida a cultura de um grupo, e no caso a das classes populares, pode servir de contestação à ordem social ou, inversamente, como modo de adesão às relações de poder.

Em sua opinião, faz-se necessário desconstruir o conceito de cultura popular, para superar uma visão ingênua do que ele consiste. A cultura popular provocaria esse impacto positivo devido ao charme da palavra “popular”. De certo modo, ela tem por base as experiências, memórias e tradições do povo, estabelecendo ligações com o cotidiano, as expectativas, os projetos, as esperanças e as aspirações das pessoas comuns. Todavia, isso não é tudo. O termo “popular” é polissêmico, ou seja, carrega vários sentidos e significados. De acordo com seu significado recorrente, uma cultura é “popular” porque as massas, o “povo”, a valoriza bastante, comprando, lendo, escutando e consumindo. Esta seria uma definição comercial ou de "mercado”, sendo frequentemente associada à alienação, expropriação e rebaixamento da cultura do povo. Contrapondo-se a ela, alguns teóricos “radicais” preconizam uma “cultura popular” alternativa, desalienada, íntegra, autêntica, que não ficaria à mercê dos interesses comerciais e à homogeneização cultural (HALL, 1984, p.93-110).

$\mathrm{Na}$ avaliação de Hall, ambas as propostas são insatisfatórias. A ideia do povo como uma “força mínima e puramente passiva” não corresponde aos fatos. As pessoas comuns não são alienadas; elas são capazes de reconhecer como suas vidas são rearranjadas, refeitas e remodeladas pela indústria cultural. Isto não significa desconhecer que a dominação cultural tenha efeitos 
concretos. Afirmar que a indústria cultural não influencia nossa vida equivale a dizer que a cultura do povo pode existir como uma ilha, algo isolado, fora do circuito no qual se configura o poder cultural e as relações de forças sociais. "Não acredito nisso”, assinala Hall. Não existe uma “cultura popular” íntegra, autêntica e autônoma, localizada fora do campo de força das relações de poder e de dominação culturais. Embora as culturas do “povo” estejam distante do poder, elas participam do campo de forças mais amplo nos quais estão inseridos os diversos segmentos sociais e culturais. Elas não apenas enfeixavam intercâmbios mútuos com a sociedade mais ampla, como ainda se vinculam a esta por meio de inúmeras tradições e práticas. Portanto, os pesquisadores têm que parar de abordar a cultura popular a partir desses dois polos intercambiáveis: do total "encapsulamento" ou da "autonomia” absoluta. Em virtude disso, o estudioso jamaicano declara optar por outra definição do conceito de cultura popular:

Essa definição considera, em qualquer época, as formas e atividades cujas raízes se situam nas condições sociais e materiais de classes específicas; que estiveram incorporadas nas tradições e práticas populares. Neste sentido, a definição retém aquilo que a definição descritiva tem de valor. Mas vai além, insistindo que o essencial em uma definição de cultura popular são as relações que colocam a 'cultura popular' em uma tensão contínua (de relacionamento, influência e antagonismo) com a cultura dominante. Trata-se de uma concepção de cultura que se polariza em torno dessa dialética cultural. Considera o domínio das formas e atividades culturais como um campo sempre variável. Em seguida, atenta para as relações que continuamente estruturam esse campo em formações dominantes e subordinadas. Observa o processo pelo qual essas relações de domínio e subordinação são articuladas. (HALL, 2003, p.255-258).

Segundo Hall, os termos “popular” e "classe trabalhadora” estabelecem relações bastante complexas, mas não devem ser tomados como sinônimos, uma vez que não existem culturas fixas, exclusivas e intrínsecas a determinada classe social. De toda sorte, o termo "popular” sugere a articulação dinâmica entre a cultura e as classes sociais. Mais precisamente, refere-se à aliança de classes e forças que constituem as "classes populares", a "cultura dos oprimidos e das classes excluídas”. Pois, no vértice oposto, tem-se a “cultura do bloco do poder”, a outra aliança de classes e forças sociais configurando o que não é o "povo” ou as “classes populares”. A contradição principal, que polariza o domínio da cultura, não se encontra no embate classe versus classe, mas sim no povo versus o bloco do poder. Nesse aspecto, a cultura popular é um campo de disputa, um dos locais de engajamento da luta a favor ou contra a “cultura dos poderosos” (HALL, 2003, p.262).

O marcador de diferenciação dentro das formas da cultura popular repousa no significante “negro”, da expressão “cultura popular negra”. Com efeito, o que essa expressão significa? O agenciamento das experiências e tradições próprias das populações negras, as quais se traduzem no 
Cultura popular: as construções de um conceito na

produção historiográfica

seu estilo, seu corpo, sua expressividade, sua musicalidade, sua oralidade e na sua rica produção de contranarrativas. Para o intelectual jamaicano, a cultura popular negra nunca pode ser reduzida ou explicada pelo viés das oposições binárias normalmente utilizadas para caracterizá-la: alto ou baixo, resistência versus cooptação, autêntico versus inautêntico, experiencial versus formal. Ela é um espaço ambivalente, paradoxal, local de intersecções, consentimentos, insurgências e contestações táticas.

Afinal, as identidades negras são formadas pela articulação dialógica entre dois eixos ou vetores em ação simultânea: o vetor de similaridade e continuidade; e o vetor de diferenciação e ruptura. O primeiro remonta-se aos elos de continuidade com o passado (a África); o segundo conecta-se às mudanças forjadas na experiência diaspórica: tráfico transatlântico, escravidão, colonização e migração. Como se sabe, os africanos escravizados procederam de diferentes nações, comunidades tribais, aldeias; falavam diversas línguas e cultuavam vários deuses. Foi o desenraizamento da escravidão e do tráfico e a inserção na grande lavoura do mundo ocidental que os unificaram, porém as diferenças persistiram. Hall relata que, ao retornar à Jamaica, sua terra natal, depois de longa ausência, sentiu na pele a "duplicidade” de similaridade e diferença. Ao visitar o Caribe francês pela primeira vez, ele notou de imediato como a Martinica é distinta da Jamaica: e não se trata de distinções de “topografia ou de clima”. É uma profunda diferença de cultura e história. E a diferença importa. Tanto literal como metaforicamente, a experiência afrodiaspórica é uma tradução. (HALL, 1996, p.70-71) ${ }^{7}$.

A gramática da cultura popular negra estabelece conexões sinuosas (e complexas) entre os signos de origens africanas e aqueles produzidos no bojo das dispersões em diáspora ao longo dos séculos, de modo que a apropriação, cooptação e rearticulação seletivas de ideologias, códigos culturais e instituições europeias, conjugados a um patrimônio africano, “conduziram a inovações lingüísticas na estilização retórica do corpo, a formas de ocupar um espaço social alheio, a expressões potencializadas, a estilos de cabelos, a posturas, gingados e maneiras de falar, bem como a meios de constituir e sustentar o companheirismo e a comunidade” (HALL, 2003, p.343).

Os repertórios culturais negros foram (e são) influenciados por matrizes galvanizadoras distintas - transmitidas tanto pelas raízes culturais africanas quanto pelas particularidades das tradições e heranças afrodiaspóricas -, por isso não existe uma cultura popular negra de maneira intacta, em formas puras. Todas suas formas são sempre o produto de sincronizações parciais, dos engajamentos que atravessam fronteiras culturais, “de confluências de mais de uma tradição cultural, de negociações entre posições dominantes e subalternas, de estratégias subterrâneas de recodificação e transcodificação, de significação crítica e do ato de significar a partir de materiais 


\section{Petrônio Domingues}

preexistentes” (Ibidem). Essas formas são a recuperação do antigo, porém de maneira dialógica, fluida e plástica, o que envolve adaptações, bricolagens ou mesmo recriações aos espaços híbridos da cultura popular.

Essas formas, por seu turno, não são essencialistas, no sentido de exprimir práticas culturais que seriam, por natureza, inerentes aos negros, como se fizessem parte de sua alma ou de seu código genético. O essencialismo, argumenta Hall, é deficiente porque "naturaliza e des-historiciza a diferença, confunde o que é histórico e cultural com o que é natural, biológico e genético”. No momento em que o significante 'negro' é arrancado de seu “encaixe histórico, cultural e político, e é alojado em uma categoria racial biologicamente constituída, valorizamos, pela inversão, a própria base do racismo que estamos tentando desconstruir” (HALL, 2003, p.345). O intelectual jamaicano insiste na ideia de que negro não é uma categoria de essência, imutável, fora da história e da cultura. Decerto existe um conjunto de experiências negras historicamente peculiares, contudo é para a diversidade e não para a homogeneidade dessas experiências que o pesquisador deve voltar o seu olhar.

\section{Considerações finais}

Cultura popular é um conceito gelatinoso, fugidio, objeto de muitas polêmicas e contendas intelectuais. Consiste num conjunto de práticas ambíguas e contraditórias, que se realizam nos interstícios da cultura dominante, recusando-a, aceitando-a ou confortando-se a ela. Qual seja, a cultura popular se caracteriza por uma combinação de resistência e conformismo (CHAUÍ, 1986). Não se define a priori - como uma fórmula preconcebida -, mas ao longo do percurso investigativo. Talvez o fundamental seja considerá-la como um instrumento que serve para auxiliar no sentido de colocar problemas, evidenciar diferenças e ajudar a compreender a realidade social e cultural (ABREU, 2003, p.84). O pressuposto de que não é possível separar cultura popular e de elite de maneira fixa, congelada e polarizada, ganha cada vez mais espaço na produção do conhecimento histórico, de modo que os pesquisadores têm se convencido de que ambas as formas culturais se comunicam e, sobretudo, são polissêmicas, mutantes, forjadas por mediações, atualizadas e reatualizadas em cada contingência histórica específica.

Os autores selecionados neste artigo afiliam-se a matrizes epistemológicas distintas. Seus textos, muitas vezes, revelam não apenas discordâncias pontuais, mas oposição de ideias, cujos significados políticos oxigenam o debate em torno de “cultura” e “popular”. Em linhas gerais, os autores consideravam a cultura popular como um processo plural, multifacetado, em constante criação e recriação; uma forma de resistência à ideologia dominante ou, ao contrário, como fruto 


\section{Cultura popular: as construções de um conceito na \\ produção historiográfica}

dessa mesma dominação, entendida como o resultado de uma relação de tensão entre os interesses dos de “cima” e os interesses dos de "baixo”, sendo uma forma cruzada, ambígua e dissimulada. Ultimamente, contudo, a cultura popular foi redefinida como um espaço de disputa, no qual se reproduzem simbolicamente as relações de forças sociais e de poder vigentes na sociedade - a cultura popular é percebida sempre do ponto de vista de suas relações de forças sociais. Como assevera Stuart Hall:

[...] Há uma luta contínua e necessariamente irregular e desigual, por parte da cultura dominante, no sentido de desorganizar e reorganizar constantemente a cultura popular; para cercá-la e confiar suas definições e formas dentro de uma gama mais abrangente de formas dominantes. Há pontos de resistência e também momentos de superação. Esta é a dialética da luta cultural. Na atualidade, essa luta é contínua e ocorre nas linhas complexas da resistência e da aceitação, da recusa e da capitulação, que transformam o campo da cultura em uma espécie de campo de batalha permanente, onde não se obtém vitórias definitivas, mas onde há sempre posições estratégicas a serem conquistadas e perdidas. (HALL, 2003, p.254).

É preciso, assim, questionar (e desconstruir) o conceito de cultura popular e ir além das dualidades (culto/popular, ilustrado/rude, refinado/arcaico, moderno/tradicional, letrado/oral) para pensar a cultura como arena de clivagens, disputas, conflitos e fraturas entre interesses antagônicos, qualificando como popular a produção cultural que se configura como manancial crítico, alternativo e contraponto à cultura hegemônica e/ou dominante. Já no que concerne à noção de “cultura popular negra”, trata-se das experiências e tradições específicas dos negros, transplantadas da África e reinventadas pelo novo repertório cultural (de práticas, artefatos e símbolos) dos afrodescendentes espargidos pelo mundo, o que encerra a contribuição da diáspora, a estética negra e as contranarrativas. Longe dos essencialismos, essa cultura é ambivalente, impura e híbrida, devendo ser inquirida conforme a sua plasticidade, diversidade e multiplicidade. Ela é luta e resistência, mas também invenção e reinvenção, apropriação e expropriação nas fronteiras da cultura popular.

Seria possível alinhavar outras correntes interpretativas para o tema deste artigo. A produção intelectual de Natalie Zamon Davis (1990), por exemplo, ficou ausente. Igualmente não foi pautada a concepção de cultura popular de Raphael Samuel (1984, p.15-47) nem a de Néstor García Canclini (1997). Enfim, se fosse para empreender uma investigação exaustiva do assunto, a lista dos autores ausentes poderia ser aumentada. Mas, como a intenção foi de sintetizar o debate, os autores e textos deslindados aqui dão uma amostra boa da importância e complexidade de um tema candente, que vem despertando o interesse de historiadores e múltiplas áreas disciplinares e diversos segmentos do mundo acadêmico. 


\section{Notas:}

\footnotetext{
${ }^{1}$ Sobre a concepção de cultura popular de Michel de Certeau, ver ainda A invenção do cotidiano: 1 . Artes de fazer. Trad. Ephraim Ferreira Alves. Petrópolis, RJ: Vozes, 1994.

${ }^{2}$ Vale lembrar que o prefácio à edição italiana foi escrito em 1976.

${ }^{3}$ De Robert Darnton, ver ainda O beijo de Lamourette: mídia, cultura e revolução. Trad. Denise Bottmann. São Paulo: Companhia das Letras, 1990.

${ }^{4}$ O problema de abandonar de vez o uso desses termos, pondera Burke (2005, p.42) "é que sem eles é impossível descrever as interações entre o erudito e o popular. Talvez a melhor política seja empregar os dois termos sem tornar muito rígida a oposição binária, colocando tanto o erudito como o popular em uma estrutura mais ampla”.

${ }^{5}$ Tomando por base uma perspectiva marxista, Gramsci procurou desenvolver um arcabouço teórico que subsidiasse a ação revolucionária dos comunistas italianos. Nesse contexto, ele identificava na cultura popular um campo potencialmente fértil para a luta ideológica e social contra o poder hegemônico. Ver GRAMSCI, Antonio. Literatura e vida nacional. Trad. Carlos Nelson Coutinho. 2. ed. Rio de Janeiro: Civilização Brasileira, 1978.

${ }^{6}$ Do ponto de vista geral, o CCCS balizou-se por três preceitos. Primeiro, que os processos culturais estão estreitamente vinculados às relações sociais, especialmente às relações e formações de classe e às opressões de gênero, raça e geração. Segundo, que a cultura forma uma esfera de poder e, o terceiro, decorrente dos outros dois, sustenta que "a cultura não é um campo autônomo nem externamente determinado, mas um local de diferenças e lutas sociais”. JOHNSON, Richard. "O que é, afinal, Estudos Culturais". SILVA, Tomaz Tadeu da (Org.). O que é, afinal, Estudos Culturais? $3^{\text {a }}$. ed. Belo Horizonte: Autêntica, 2006, p. 12. Ver também CEVASCO, Maria Elisa. Dez lições sobre Estudos Culturais. São Paulo: Boitempo, 2003.

${ }^{7}$ Conforme sublinha Hall (2003, p.346), "não é somente para apreciar as diferenças históricas e experiências dentro de, e entre, comunidades, regiões, campo e cidade, nas culturas nacionais e entre as diásporas, mas também reconhecer outros tipos de diferenças que localizam, situam e posicionam o povo negro”.
}

\section{Referências:}

ABREU, M. Cultura popular: um conceito e várias histórias. In: ABREU, M.; SOIHET, R. (Orgs.). Ensino de História: conceitos, temáticas e metodologia. Rio de Janeiro: Casa da Palavra, 2003, p. 83-102.

BAKHTIN, M. A cultura popular na Idade Média e no Renascimento: o contexto de François Rabelais. Trad. Yara Frateschi Vieira. São Paulo: Hucitec; Brasília: Editora da UnB, 1987.

BURKE, P. Cultura popular na Idade Moderna. Trad. Denise Bottmann. 2. ed. São Paulo: Companhia das Letras, 1989.

BURKE, P. Cultura erudita e cultura popular na Itália renascentista, In: BURKE, P. Variedades de história cultural. Trad. Alda Porto. Rio de Janeiro: Civilização Brasileira, 2000, p. 177-193.

BURKE, P. O que é história cultural? Trad. Sérgio Góes de Paula. Rio de Janeiro: Jorge Zahar, 2005.

CANCLINI, N. G. Culturas híbridas: estratégias para entrar e sair da modernidade. Trad. Ana Regina Lessa e Heloísa Pezza Cintrão. São Paulo: EDUSP, 1997.

CERTEAU, M. de; JULIA, D.: REVEL, J. A beleza do morto: o conceito de cultura popular. A invenção da sociedade. Trad. Vanda Anastácio. Lisboa: Difel, 1989.

CHARTIER, R. A história cultural: entre práticas e representações. Trad. Maria Manuela Galhardo. São Paulo: Difel, 1988.

CHARTIER, R. Cultura popular: revisitando um conceito historiográfico. Estudos Históricos, n.16, p. 179-192, 1995. 
CHAUÍ, M. Conformismo e resistência: aspectos da cultura popular no Brasil. São Paulo: Brasiliense, 1986.

DARNTON, R. O grande massacre de gatos, e outros episódios da história cultural francesa. Trad. Sônia Coutinho. 4. ed. Rio de Janeiro: Graal, 2001.

DAVIS, N. Z. Culturas do povo: sociedade e cultura no início da França moderna. Trad. Mariza Correa. Rio de Janeiro: Paz e Terra, 1990.

GINZBURG, C. O queijo e os vermes: o cotidiano e as idéias de um moleiro perseguido pela Inquisição. Trad. Maria Betânia Amoroso. 3. ed. São Paulo: Companhia das Letras, 2002.

HALL, S. Da diáspora: identidades e mediações culturais. Trad. Adelaine La Guardiã Resende et al. Belo Horizonte: Ed. UFMG; Brasília: Representação da Unesco no Brasil, 2003.

HALL, S. Notas sobre La desconstrucción de 'lo popular'. In: SAMUEL, R. (Org.). Historia popular y teoria socialista. Barcelona: Editorial Crítica, 1984. p. 93-110.

HALL, S. Identidade cultural e diáspora. Revista do Patrimônio Histórico e Artístico Nacional, n. 24, 1996, p. 70-71.

JOHNSON, R. O que é, afinal, Estudos Culturais. In: SILVA, T. T. da (Org.). O que é, afinal, Estudos Culturais? 3a. ed. Belo Horizonte: Autêntica, 2006, p. 07-131.

MATTELART, A.; NEVEU, É. Introdução aos estudos culturais. Trad. Marcos Marcionilo. São Paulo: Parábola Editorial, 2004.

REVEL, J. A invenção da sociedade. Trad. Vanda Anastácio. Lisboa: Difel, 1989.

REVEL, J. Proposições: ensaios de história e historiografia. Trad. Claudia O’Connor dos Reis. Rio de Janeiro: EdUERJ, 2009.

SAMUEL, R. Historia popular, historia del pueblo. In: SAMUEL, R. (Org.). Historia popular y teoria socialista. Barcelona: Editorial Crítica, 1984. p. 15-47.

THOMPSON, E. P. Costumes em comum: estudos sobre a cultura popular tradicional. Trad. Rosaura Eichemberg. São Paulo: Companhia das Letras, 1998.

THOMPSON, E. P. As peculiaridades dos ingleses e outros artigos. In: NEGRO, A. N.; SILVA, S. (Orgs.). Campinas, SP: Editora da Unicamp, 2001.

VOVELLE, M. O popular em questão. In: Ideologias e mentalidades. Trad. Maria Julia Cottvasser. $2^{\mathrm{a}}$. ed. São Paulo: Brasiliense, 1991, p. 151-224.

Recebido em: 21/09/2010

Aprovado em: 01/06/2011. 